\title{
酸化鉄の還元がハイパーコールを配合した フェロコークスの強度に及ぼす影響
}

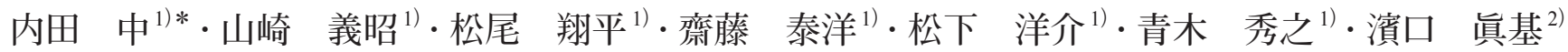

Effect of Iron Ore Reduction on Ferro-coke Strength with Hyper-coal Addition

Ataru Uchida, Yoshiaki Yamazaki, Shohei Matsuo, Yasuhiro Saito, Yohsuke Matsushita, Hideyuki Aoki and Maki Hamaguchi

Synopsis : This study investigates the dominant factors affecting the strength of ferro-coke, which is produced by blending iron oxide with coal particles, with the addition of hyper-coal (HPC), to produce a high reactivity and strong coke. A diametral compression test for ferro-coke with and without HPC addition is performed. A three-dimensional ferro-coke model is then developed using micro X-ray computed tomography, and the relative proportions of pore, pore wall, iron, and pore space surrounding the iron particles, termed here "defect", are quantified using this model. Moreover, a stress analysis is performed for the ferro-coke model. The diametral compression tests indicate that the strength of ferro-coke increases with the increasing blending ratio of HPC. The image-based modeling indicates that the wall thickness increases and stress concentration is relaxed with increasing addition of HPC due to enhancement of the adhesiveness of coal particles. On the other hand, the relative proportion of the "defect" is independent of HPC addition. Therefore, ferro-coke strength is found to be determined not by the "defect" around iron oxide but by the wall thickness.

Key words : ferro-coke; hyper-coal; coke strength; 3D analysis; microstructure; micro X-ray computed tomography.

\section{1. 緒言}

高炉操業において，コークスには還元材，空隙維持材と 熱源としての役割があり，高炉の安定操業にはコークスの 強度が重要である ${ }^{1,2)}$ 。近年，炭素資源を有効利用し，高炉 の効率を向上させるために高反応性コークスを使用するこ とが求められている ${ }^{3,4)}$ 。高反応性コークスを使用すること で銑鉄を製造する際に使用する炭材の指標である還元材比 が減少することが報告されており ${ }^{5,6)}$, 高反応性コークスが ますます注目されている。高反応性コークスの1つにコー クス製造時に鉄鉱石を配合したフェロコークスがある。

これまでフェロコークスの反応性および強度について 広く検討されている。Nomura ら $^{7)}$ は, フェロコークスは高 い反応性を有するものの, 鉄鉱石により石炭粒子の膨張性 が低下することを報告している。また, Yamazakiらは鉄鉱 石により石炭粒子の膨張性が低下することで石炭粒子の 接着性が低下し，コークス強度が低下することを報告して いる ${ }^{8)}$ 。Yamamoto らは性状の異なる原料の配合比を変えて フェロコークスを製造し，同じ反応率の室炉コークスと比 較してほぼ等しい反応後強度を示す条件があることを示し
ている ${ }^{9)}$ ここれらの研究では, 乾留後のフェロコークスの 反応性および強度について検討しているが，乾留過程にお ける鉄鉱石の還元反応の影響については議論されていな い。そのため，フェロコークスの強度を支配している因子 を特定し，フェロコークスの乾留で生じる現象を理解する 必要がある。

コークスの強度を向上させるためにコークス製造時に バインダーとして HPC (Hyper-coal) を配合する手法が検 討されている。HPC は低温から溶融し, 高い流動性を示す ため, HPCを低品位炭に配合することでコークス強度を向 上させることが可能である ${ }^{10)}$ 。Uchida ${ }^{11)}$ はフェロコーク スでは鉄粒子が石炭粒子の間隙に存在し，石炭粒子同士の 接着を阻害することを報告している。しかしながら，フェ ロコークスにHPCを配合することで石炭粒子同士の接着 が改善するだけでなくコークス強度が向上し, 石炭粒子同 士の接着がコークス強度の支配因子の1つであると結論づ けている。また, UchidaらはHPCがフェロコークスの微視 構造の形成に及ぼす影響を検討し, HPCが酸化鉄の影響を 受けながらも軟化溶融温度において石炭粒子同士の接着 性の向上に寄与することを示している ${ }^{12)}$ 。したがって，石

原著論文：ISIJ Int., Vol.56 (2016) , No.12, pp.2132-2139, 澤村論文賞受賞論文 (2018 年表彰)

2019年4月18日受付２019年5月31日受理（Received on Apr. 18, 2019 ; Accepted on May 31, 2019 ; originally published in ISIJ Int., Vol.56, 2016, No.12, pp.2132-2139 and reprinted at the request of the ISIJ Editorial Board because the original paper received the Sawamura Award in March 2018.)

1）東北大学大学院工学研究科化学工学専攻 (Department of Chemical Engineering, Graduate School of Engineering, Tohoku University, 6-6-07 Aramaki Aoba Aoba-ku Sendai Miyagi 980-8579)

2) (株) 神戸製鋼所 (Kobe Steel, Ltd.)

* Corresponding author : E-mail : matsushita@tranpo.che.tohoku.ac.jp

DOI : https://doi.org/10.2355/tetsutohagane.TETSU-2019-046 
炭, HPC および鉄鉱石の配合比は微視構造および強度に影 響を及ぼすことがわかる。微視構造の変化により軟化溶融 温度に打いて酸化鉄によって石炭粒子同士の接着性が変化 するとともに再固化温度以降において酸化鉄の還元によっ て HPC および石炭の基質が減少する。コークスの微視構造 と強度について検討するため, Hiraki ら ${ }^{13)}$ はマイクロX線 CT (Computed Tomography) を用いて撮像したフェロコー クスの断面の画像を用いてコークスの微視構造を再現し， 応力解析打よびLindquist $~^{14)}$ が提案する三次元構造を考 慮した気孔壁厚さを定量的に評価した。その結果，三次元 的に評価した気孔壁厚さとコークス強度の関係を見出し， 気孔壁厚さとコークスの強度を用いて石炭粒子同士の接着 性を検討することが可能であることを示した。しかしなが ら，コークスの微子構造における気孔壁厚さと酸化鉄粒子 の存在およびコークス強度の関係は定量的に評価されてい ない。

そこで本研究では，割裂引張試験により測定したコー クスの強度とマイクロ X線 CT 画像から構築した三次元の フェロコークスの微視構造に基づく応力解析から求めた コークスの強度を比較する。フェロコークスの微視構造の 評価には，三次元の微細構造における気孔壁厚さおよび鉄 粒子周辺に生じた“欠陷”を用いた。三次元の微細構造に おける気孔壁厚さは石炭粒子同士の接着性を，“久陥” は乾 留過程において酸化鉄の還元反応に伴い減少したコークス 基質をそれぞれ表す。

Table 1. Proximate analyses for Donaldson coal and HPC [wt $\%]$.

\begin{tabular}{cccc}
\hline & Moisture & Ash & VM \\
\hline & & {$[\mathrm{wt} \%]$} & \\
\hline Donaldson coal & 3.4 & 7.6 & 40.2 \\
HPC & 0.3 & 0.1 & 41.2 \\
\hline
\end{tabular}

Table 2. Ultimate analyses for Donaldson coal and HPC [wt $\%$ daf].

\begin{tabular}{ccccccc}
\hline & $\mathrm{C}$ & $\mathrm{H}$ & $\mathrm{N}$ & $\mathrm{S}$ & $\mathrm{O}(\mathrm{diff})$ & $\mathrm{H} / \mathrm{C}$ \\
\hline & & & {$[\mathrm{wt} \% \mathrm{daf}]$} & & & {$[-]$} \\
\hline $\begin{array}{c}\text { Donaldson } \\
\text { coal }\end{array}$ & 80.4 & 5.6 & 1.8 & 0.7 & 11.5 & 0.84 \\
HPC & 86.6 & 5.4 & 1.9 & 0.6 & 5.5 & 0.75 \\
\hline
\end{tabular}

\section{2. 実験および解析方法}

\section{$2 \cdot 1$ 試料}

Table 1-3に本研究で使用した原料の性状を示す。試料と して微粘結炭であるドナルドソン炭を, バインダーとし て HPCを，鉄源として鉄鉱石（MBR）をそれぞれ用いる。 Table 4 に本研究で使用した HPCの軟化溶融開始温度, 最高 流動度温度，再固化温度および最高流動度を示す。Table 5 に試料の粒径を，Table 6に試料A-Dの配合比をそれぞれ示 す。なお，乾留条件は既報 ${ }^{11)}$ と同様である。割裂引張試験 に用いた試料は径 $25 \mathrm{~mm}$ ，厚さ $15 \mathrm{~mm}$ である。径 $7 \mathrm{~mm}$ と $3 \mathrm{~mm}$ の試料も作製し, 径 $7 \mathrm{~mm}$ の試料はフェロコークスの 微細構造の, 径 $3 \mathrm{~mm}$ の試料は酸化鉄粒子周りの気孔構造 の検討にそれぞれ用いる。

\section{$2 \cdot 2$ 乾留後のコークスの強度の評価}

既報 ${ }^{11)}$ の割裂引張試験と同様に $1000^{\circ} \mathrm{C}$ で乾留した試料 の引張強度を測定し，ワイブルプロットを用いてスケール パラメータを算出する。なお，各条件に対して試験を 14 あ るいは 15 回実施した。

\section{$2 \cdot 3$ 三次元のフェロコークスモデルの構築}

複雑な形状を持つ気孔や組織が存在するため，コークス の微視構造を検討することは困難である ${ }^{15)}$ 。近年，デジタ

Table 4. Physical properties obtained by Gieseler plastometer for Donaldson coal and HPC.

\begin{tabular}{ccccc}
\hline & $\begin{array}{c}\text { Initial } \\
\text { softening } \\
\text { temperature } \\
{\left[{ }^{\circ} \mathrm{C}\right]}\end{array}$ & $\begin{array}{c}\text { Maximum } \\
\text { fluidity } \\
\text { temperature } \\
{\left[{ }^{\circ} \mathrm{C}\right]}\end{array}$ & $\begin{array}{c}\text { Resolidification } \\
\text { temperature }\left[{ }^{\circ} \mathrm{C}\right]\end{array}$ & $\begin{array}{c}\log _{10} \mathrm{MF} \\
{[\mathrm{ddpm}]}\end{array}$ \\
\hline $\begin{array}{c}\text { Donaldson } \\
\text { coal }\end{array}$ & 408 & $430-436$ & 451 & 0.78 \\
\hline HPC & 242 & $351-436$ & 476 & $>4.8$ \\
\hline
\end{tabular}

Table 5. Average particle size of Donaldson coal, HPC, and MBR [mm]

\begin{tabular}{ccc}
\hline Donaldson coal & HPC & MBR \\
\hline & {$[\mathrm{mm}]$} & \\
\hline$<1.0$ & $<0.15$ & $<0.25$ \\
\hline
\end{tabular}

Table 6. Blending ratios of Donaldson coal, HPC, and MBR for samples A-D [\%].

\begin{tabular}{cccc}
\hline Sample & Donaldson coal & HPC & MBR \\
\hline & & {$[\%]$} & \\
\hline A & 70 & 0 & \\
B & 65 & 5 & 30 \\
C & 60 & 10 & \\
D & 55 & 15 &
\end{tabular}

Table 3. Chemical composition for MBR.

\begin{tabular}{ccccccccccccccccc}
\hline $\mathrm{T}-\mathrm{Fe}$ & $\mathrm{FeO}$ & $\mathrm{SiO}_{2}$ & $\mathrm{CaO}$ & $\mathrm{Al}_{2} \mathrm{O}_{3}$ & $\mathrm{MgO}$ & $\mathrm{P}$ & $\mathrm{S}$ & $\mathrm{Na}$ & $\mathrm{K}$ & $\mathrm{TiO}$ & $\mathrm{Mn}$ & $\mathrm{Zn}$ \\
\hline 67.5 & 0.21 & 1.31 & 0.01 & 0.73 & 0.01 & 0.033 & 0.01 & 0.01 & 0.01 & 0.07 & 0.11 & 0.003 \\
\hline
\end{tabular}


ルイメージに基づくモデリングが複雑な形状を持つ複合材 料の再現 ${ }^{16)}$ および実測困難な生体骨の海綿組織の成長の 評価 ${ }^{17)}$ に広く適用されている。本研究では，フェロコーク スの微細構造を検討するためおよび応力解析の解析対象を 作成するためにデジタルイメージに基づくモデリングを用 いて三次元のフェロコークスモデルを構築する。

上述したフェロコークス試料の三次元構造の再現にはX 線CT（Scan Xmate D160TS110，コムススキャンテクノ製）

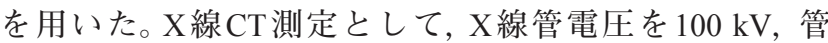
電流を $100 \mu \mathrm{A}$ とした。径 $7 \mathrm{~mm}$ と $3 \mathrm{~mm}$ のフロコークス

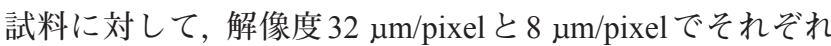
140 枚と 250 枚のX線 CT像を取得した。Fig.1 (a) - (d) に 試料 A-DのX線CT像をそれぞれ示す。灰色の部分はコー クス基質，黒い部分は気孔であり，白い部分は死分あるい は鉄粒子である。灰分および鉄粒子はX線がコークス基質 と比較して透過しにくいため白くなる。

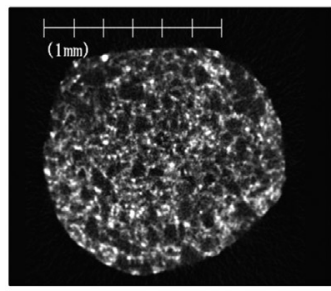

(a) Sample A (HPC: 0 wt\%)

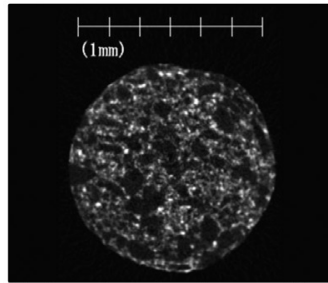

(c) Sample C (HPC: $10 \mathrm{wt} \%)$

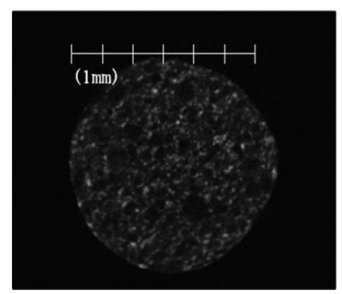

(b) Sample B (HPC: 5 wt\%)

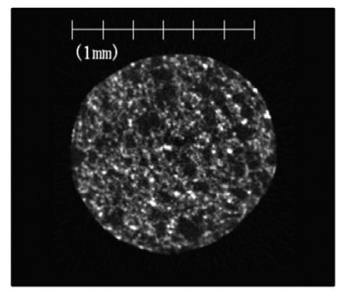

Black: Pore

Gray: Matrix

White: Iron

(d) Sample D (HPC: $15 \mathrm{wt} \%$ )

Fig.2 に三次元のフェロコークスモデルの構築方法の手 順を示す。まず, 画像処理ソフトウェア (WinRoof ver. 6.1.0) を用いて，断面の画像をグレースケール変換し，濃淡值の ヒストグラムに基づき，コークス基質あるいは気孔，灰分 と鉄粒子の二值化画像を作成する。なお，二值化画像に占 めるコークス基質，気孔および金属鉄の割合を用いて，X 線 CT像のしきい值を設定した。最後に，断面の画像を積み 重ね，ピクセルの高さをそれぞれ $32 \mu \mathrm{m} / \mathrm{pixel}$ と $8 \mu \mathrm{m} / \mathrm{pixel}$ と仮定することでボクセルとして径 $7 \mathrm{~mm}$ と $3 \mathrm{~mm}$ のサン プルの三次元のフェロコークスの構造を構築する。

\section{$2 \cdot 4$ 三次元構造における気孔壁厚さの評価}

Fig.3に気孔壁厚さを評価するために用いたアルゴリズ ムの概念図を示す。本研究では, Lindquist $~^{14)}$ の提案する 方法を適用し, 三次元応力解析の結果とコークス気孔壁厚 さの関係を検討する。Fig.3に示すように，気孔のボクセル を number 0 と定義し，気孔のボクセルに接している基質の ボクセルを number 1 として定義する。 number 1 に接してい る基質のボクセルを number 2 と定義し，これを繰り返す。 この手順を各気孔の境界から実施する。番号の大きいボク セルほど気孔から遠いため, 気孔壁が厚くなることを意味 する。この方法を用いてコークス基質の頻度分布を計算す ることで気孔壁厚さを評価する。

\section{$2 \cdot 5$ 鉄粒子周辺における “欠陥”の定量評価}

乾留後のフェロコークスの微視構造における鉄粒子周 辺の気孔を評価する。例えば，試料 AのCT画像 (分解能 $8 \mu \mathrm{m} / \mathrm{pixel})$ から構築した微視構造の三次元像の断面にお いて, Fig.4に示す鉄粒子およびコークス基質の間隙におけ る濃い灰色の正方形で表す気孔を “欠陥”と定義する。“欠 陷”の抽出過程はFig.4に示すとおりである。まず, Fig.2に 示すと打りに画像処理を行い，コークス基質，鉄粒子およ び気孔に分類する（Fig.4 (a)）。鉄粒子の周りの気孔，つま り “欠陥”を評価するため, “欠陥”はまず “欠陷候補”とし

Fig. 1. Micro X-ray CT images of the ferro-coke samples A-D.

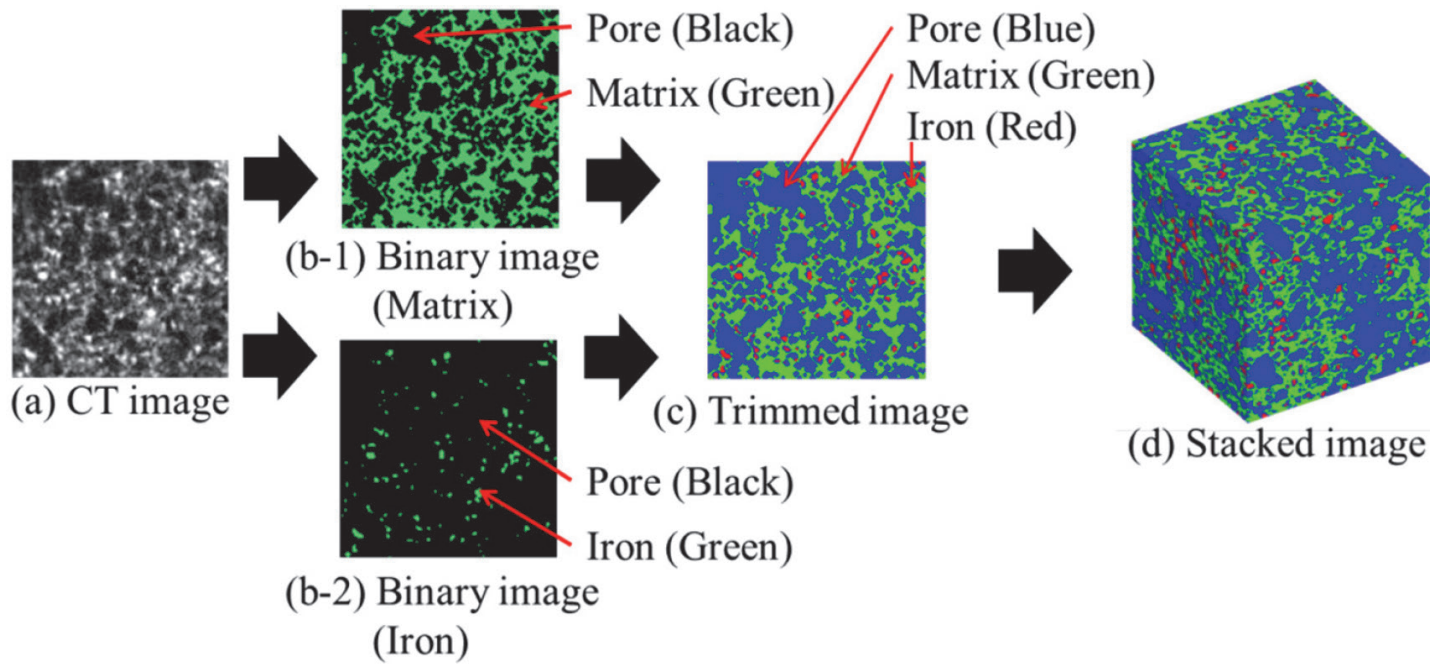

Fig. 2. Construction procedure for the image-based three-dimensional ferro-coke model. (Online version in color.) 
てラベリングする。Fig.4（b）に示すとおり，鉄粒子に隣接 する気孔を “欠陷候補”number 1 としてラベリングし，“欠 陷候補”number 1 に隣接する気孔を“欠陥候補”number 2 としてラベリングし，この手順を5回繰り返す。しかしな がら，この手順によりほとんどの気孔が “欠陷候補”に分 類され，“欠陥”が過大に見積もられてしまう。そのため， “欠陷候補”から “欠陷”之気孔を区別し, “欠陷”を抽出す る必要がある。Fig.4の画像処理によって輝度值分布が求 められ，適切なしきい值を設定することによって，基質， 鉄粒子および気孔を区別する。これにより, 不完全な気孔 (“欠陷”) から通常の気孔を区別することが可能となる。 そのため, Fig.4 (b) から Fig.4 (c) を差し引くことでFig.4 (d) に示すように“欠陥”を抽出することができる。

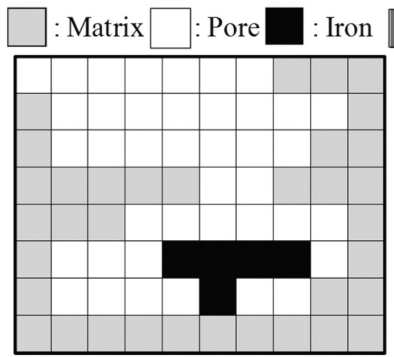

(a) Original

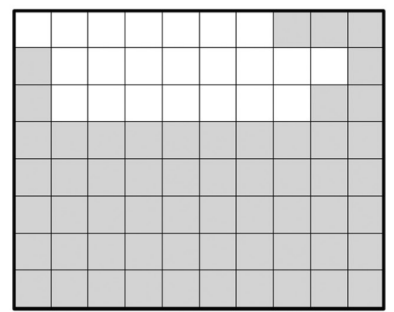

(c) Tentative matrix (except pore)
: Defect 1-5: Prospective defect

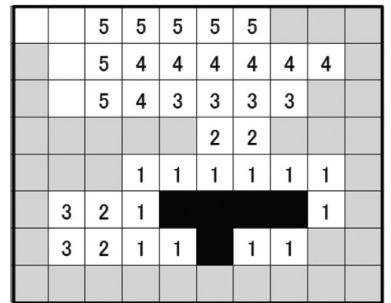

(b) Matrix, Iron and Prospective defect

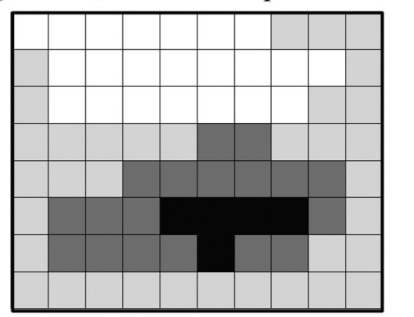

(d) After analysis
Fig. 4. Schematic of the algorithm for extracting the "defect".

\section{$2 \cdot 6$ 有限要素法を用いた数値解析}

フェロコークスの微細構造が応力集中に及ぼす影響を検 討するため, $\mathrm{FEM}^{18)}$ を用いて Table 6 に示す試料 A-D に対し て三次元応力解析を実施する。前節で定義したフェロコー クスの微細構造中の “欠陥”の大きさはマイクロメーター・ オーダーであり，HPCの配合が “欠陥”に及ぼす影響を検 討するためには微細な構造を解像する必要がある。そのた め, 代表体積が $32^{3} \mu \mathrm{m}^{3}$ や $8^{3} \mu \mathrm{m}^{3}$ のボクセルに基づく有限 要素メッシュを Fig.2 (d) に示す解析対象に適用する。

微小の弾性変形に対する基礎式を式 (1) - (3) に示す。

$$
\begin{aligned}
& \sigma_{i j, j}+F_{i}=0 \ldots \ldots \ldots \ldots \\
& \sigma_{i j}=E_{i j k l} \varepsilon_{k l} \ldots \ldots \ldots \ldots \\
& \varepsilon_{i j}=\frac{1}{2}\left(u_{i, j}+u_{j, i}\right)
\end{aligned}
$$

本解析では，支配方程式を有限要素法により離散化する。 なお，計算には 8 節点アイソパラメトリック要素を用いる。 並列計算を実施し, Element by element法に基づく共役勾配 （CG）法を用いて各節点の変位を算出する。

Fig.2 (d) に示す解析対象に対して単軸引張試験を想定 した応力解析を実施する。境界条件として, 解析領域の下 部の節点を拘束し，上部の節点には引張方向に強制変位に よる反力の総和を断面積で除した值が $1 \mathrm{MPa}$ となる強制変 位を与えた。解析では，コークス基質がナノインデンテー ション法 ${ }^{19,20)}$ を用いて測定した弾性係数 $24 \mathrm{GPa}$ とポアソ ン比 0.3 の活性成分で構成されているとする。また, 気孔 の弾性係数はコークス基質の弾性係数の $10^{-4}$ 倍小さいと 仮定する。金属鉄は微視構造に生じる応力を分散させない ため，気孔と同様に扱う ${ }^{21)}$ 。気孔には仮定した材料物性を 与えたものの，本解析結果が気孔にメッシュを生成しな い場合の結果と良好に一致することを確認している。な

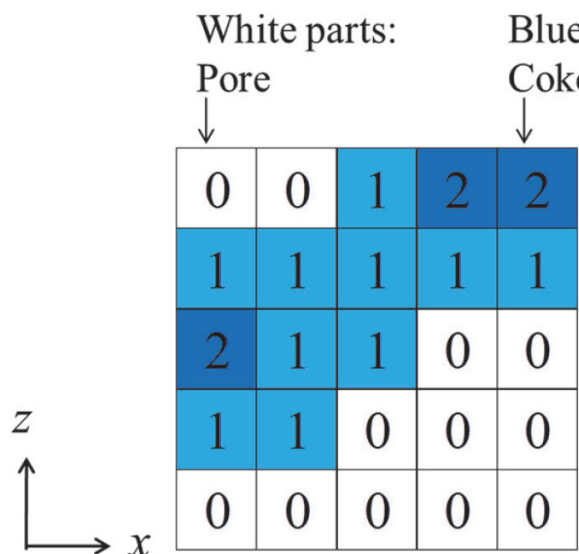

(a) $y=i+1$

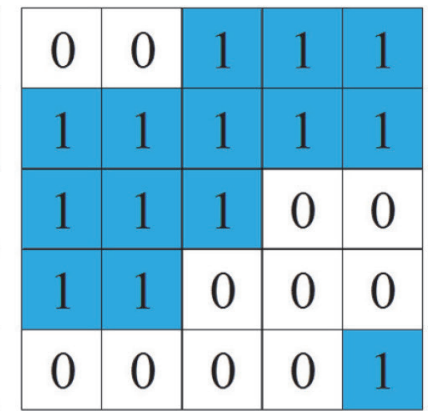

(b) $y=i$

\begin{tabular}{|l|l|l|l|l|}
\hline 0 & 0 & 0 & 0 & 0 \\
\hline 0 & 0 & 1 & 0 & 0 \\
\hline 0 & 1 & 0 & 0 & 0 \\
\hline 0 & 0 & 0 & 0 & 0 \\
\hline 0 & 0 & 0 & 0 & 0 \\
\hline
\end{tabular}

(c) $y=i-1$

$i$ :Natural number

Fig. 3. Schematic of the algorithm for evaluating the pore wall thickness. (Online version in color.) 
お，コークスは，ぜい性破壊を示すことが知られているた め ${ }^{19)}$ ，ぜい性材料に用いられる最大主応力を用いて解析結 果を評価する。ここで, 主応力とはせん断応力がゼロにな る座標の垂直応力である。

\section{3. 結果と考察}

\section{$3 \cdot 1$ HPC 配合に伴うコークス強度の変化}

割裂引張試験の測定結果から算出した試料 A-Dのワイ ブルプロットをFig.5に，そのスケールパラメータを Fig.6 に示す。HPCを配合することでスケールパラメータが増加 し, HPCの添加によりフェロコークスの強度が増加するこ とがわかる。これは既報 ${ }^{11)}$ で議論したようにHPCを配合 することで石炭粒子の接着性が向上したためである。した がって, HPCの配合によりフェロコークスの微視構造が変 化し，フェロコークスの基質に生じる応力分布が変化する

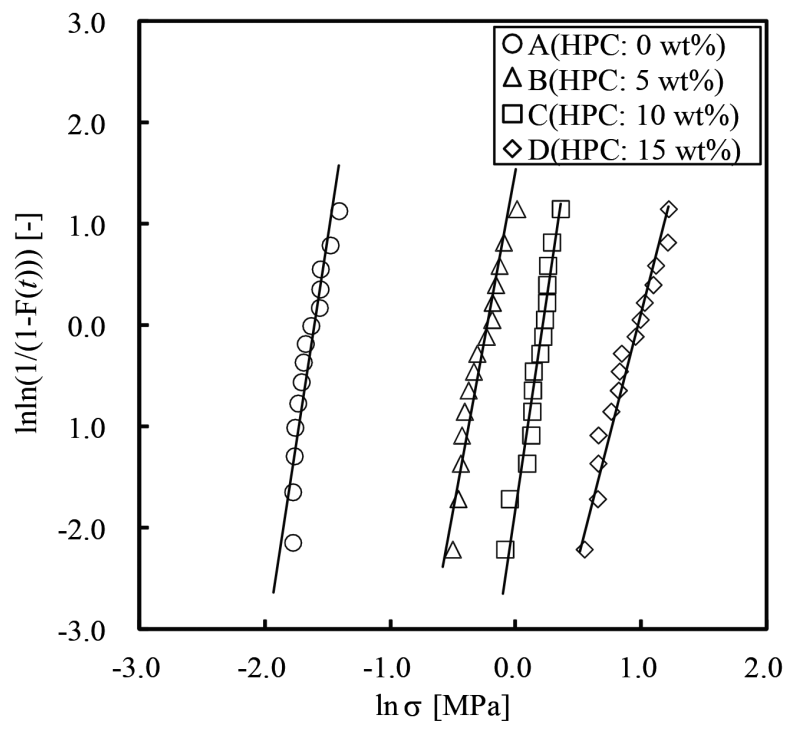

Fig. 5. Weibull plots for samples A-D.

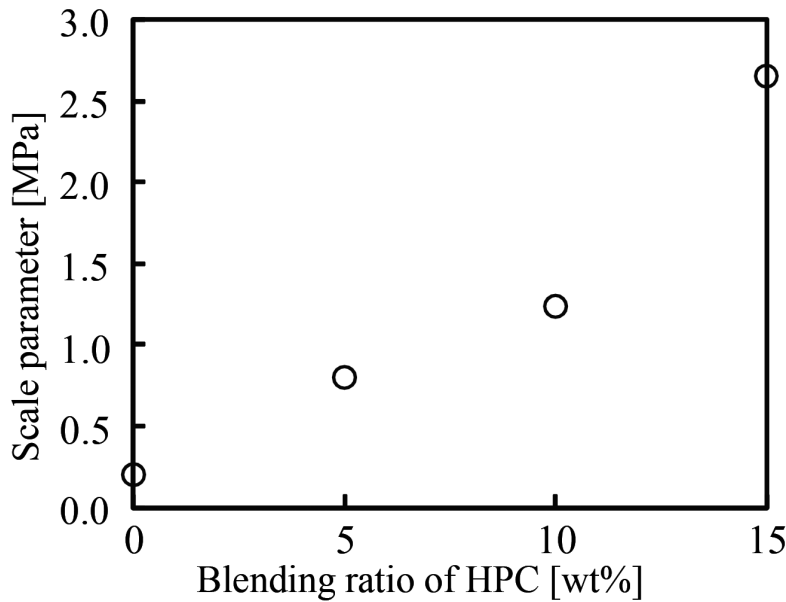

Fig. 6. The scale parameters of the Weibull plots given in Figure 5 for the blending ratios of HPC.

と考えられる。そこで, CT画像からフェロコークスの三次 元微視構造を再現し，気孔壁厚さを評価するとともに“欠 陷”を抽出する。また, HPC配合に伴うフェロコークス微 視構造の変化が応力解析の結果に及ぼす影響について考察 し，フェロコークスの強度支配因子を検討する。

\section{$3 \cdot 2$ 三次元微視構造における気孔壁厚さの評価}

HPC 配合に伴うフェロコークスの気孔壁厚さのマイク ロスケールの变化を定量的に評価するため, 三次元で再現 した試料A-Dの微視構造の気孔壁厚さを測定した。試料 A-Dの三次元微視構造のパラメータを Table 7 に, 試料 A と Dの断面図をFig.7にそれぞれ示す。なお，解析領域の分解 能が $32 \mu \mathrm{m}$ であるため, 石炭粒子内部における $32 \mu \mathrm{m}$ 以下 のコークス基質は表現できない。Fig.8 試料A-Dの三次元 微視構造の気孔壁厚さを示す。なお, 横軸の number は Fig.3

Table 7. Existence ratios of pore, matrix, iron, and "defect" in the ferro-coke model for samples A-D [\%].

\begin{tabular}{crrrr}
\hline Sample & A & B & C & D \\
\hline & \multicolumn{5}{c}{$[\%]$} \\
\hline Pore & 67.2 & 67.4 & 61.6 & 65.7 \\
Matrix & 28.9 & 28.9 & 35.3 & 31.4 \\
Iron & 3.9 & 3.7 & 3.1 & 2.9 \\
\hline Defect & 2.0 & 2.0 & 1.7 & 1.6 \\
\hline
\end{tabular}

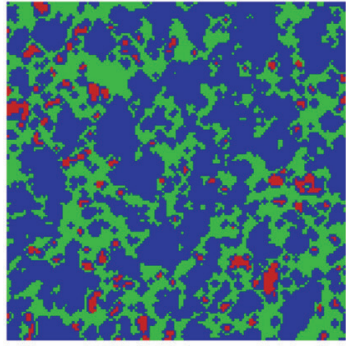

(a) Sample A (Donaldson coal/HPC Iron $=70 / 0 / 30$ )

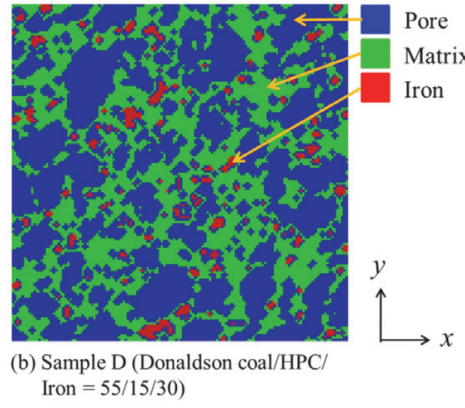

Fig. 7. Cross-sectional images of the ferro-coke model, including the pore, matrix, and iron, for samples A and D. (Online version in color.)

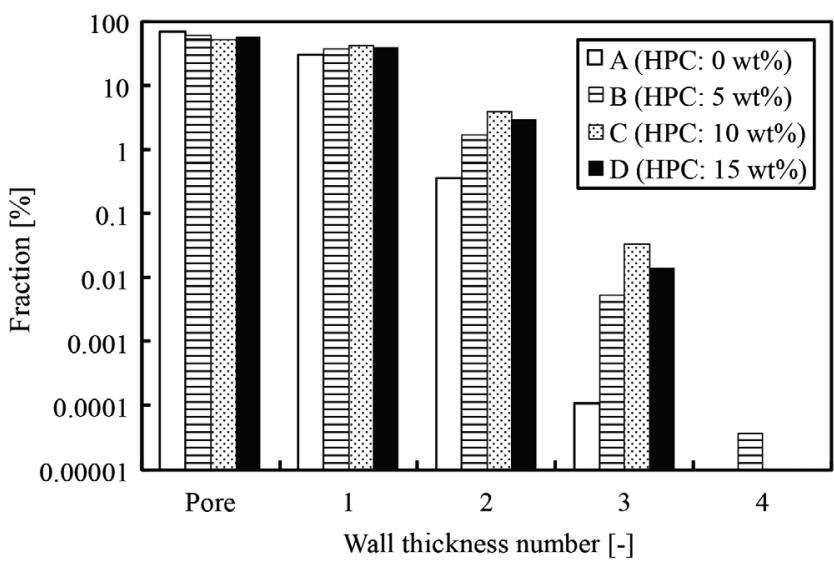

Fig. 8. Existence ratios of the pore and matrix (each wall thickness number) for samples A-D. 
中の值に対応し，この值が大きな基質はコークス基質の 内部に存在し，コークス基質が厚いことを表す。試料Dを 除き，HPCを配合することで気孔が減少し, number 1-4の 基質の割合が増加した。そのため, HPCを配合することで フェロコークス中の気孔壁が厚くなることがわかる。微視 構造は乾留過程に打いて酸化鉄の影響を受けながら形成さ れる。Nomura $5^{7)}$ は酸化鉄の配合によって石炭の溶融成分 の分解が起こり，石炭粒子の膨張性が低下することを報告 した。また, Uchida ${ }^{12)}$ はHPCの溶融成分が酸化鉄により 分解されながらも石炭粒子の接着性を向上させることを報 告した。そのため, HPCの配合により，石炭粒子の溶融成 分の分解が抑制され，石炭粒子の膨張性の低下が起こりに くくなり，その結果，石炭粒子の接着性が向上し，気孔壁 が厚くなったと考えられる。試料Aでは軟化溶融温度にお いて酸化鉄により石炭の溶融成分が分解され，石炭粒子の 膨張性が低下すると考えられる。一方，試料Dでは，HPC の溶融成分により酸化鉄による石炭の溶融成分の分解が抑 制され，石炭粒子が膨張しやすく石炭粒子の接着性が良好 になったと考えられる。この影響は本研究の解像度では気 孔壁厚さには表れず，さらに高い解像度で気孔壁を評価す るか接着性を評価可能な他のパラメータを用いることで, HPCの配合量が多い場合のコークスの強度の増加を予測 することが可能であると考えられる。

\section{3・3 鉄粒子周辺における微視構造の变化（“欠陥”）}

Fig.7に示し，前節で議論したと抢り，鉄粒子の周りに空 隙が生成し, 本研究では鉄粒子の周りに生成した空隙を “欠陥”と定義している。空隙は鉄粒子の周りに生成するた め, コークス基質を消費しながら酸化鉄の還元反応が進行 すると考えられる。再固化温度以降に扔いて鉄粒子の周り において酸化鉄の還元によって生成する “欠陥”を検討す るため, “欠陥”を抽出する。

$\phi 3$ のフェロコークス試料を分解能 $8 \mu \mathrm{m} / \mathrm{pixel}$ で撮像し, $2.0 \mathrm{~mm} \times 2.0 \mathrm{~mm} \times 2.0 \mathrm{~mm}$ で再現したフェロコークスの微 視構造について検討する。Fig.9 試料 $\mathrm{A}$ と Dのコークス基 質，気孔，鉄粒子および“欠陥”の分類結果を示し，Table 7

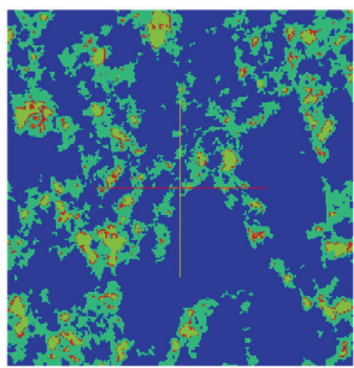

(a) Sample A (Donaldson coal/HPC/ $\mathrm{MBR}=70 / 0 / 30$

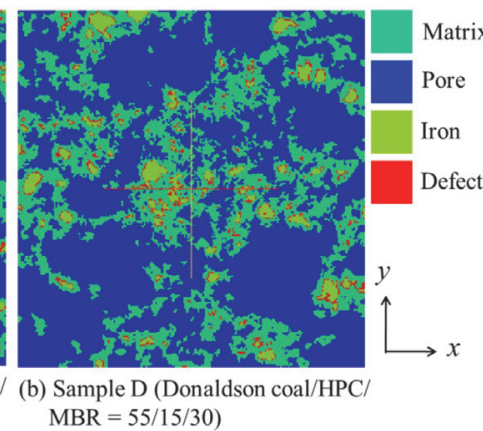
$\mathrm{MBR}=55 / 15 / 30)$
Fig. 9. Cross-sectional images of the ferro-coke model, including the pore, matrix, iron, and "defect", for samples A and D. (Online version in color.)
にフェロコークスの三次元微視構造の断面図の定量結果 を示す。HPCの配合を増加させた場合, 顕著な差は現れな かったものの, “欠陥”の割合はわずかに減少した。Uchida $ら^{12)}$ は，乾留過程に打いて酸化鉄はHPCの配合比に関係

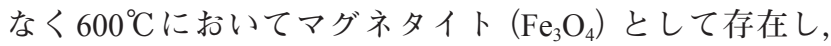
高温域に打いて進行する酸化鉄の還元反応の割合は一定で あることを報告している。そのため, $600^{\circ} \mathrm{C}$ 以降に打いてマ グネタイトからウスタイト $(\mathrm{FeO})$ を経由して金属鉄に還 元され，コークス基質が減少することが考えられる。一方， 軟化溶融温度に打いて, ヘマタイト $\left(\mathrm{Fe}_{2} \mathrm{O}_{3}\right)$ は石炭また はHPCの溶融成分の水素原子により還元反応が促進され る ${ }^{12)}$ 。さらにHPC は石炭よりも流動性が高いため, 酸化鉄 と接触する割合が高く，酸化鉄の還元反応を促進させる。 その結果, 再固化温度において, HPCの配合量にともない 酸化鉄の還元率に差が生じ, 軟化溶融温度において還元さ れなかった未還元のへマタイトの還元反応により “欠陥” が生じると考えられる。Table 7 に示す “欠陥” は，再固化温 度以降に打けるマグネタイトの還元反応により生じた“久 陷”および軟化溶融温度に打いて還元されなかったへマタ イトの還元反応により生じた“欠樎”であると考えられる。 また，HPCを配合することでわずかに減少した“欠陥”は， 軟化溶融温度に打いて還元されなかった未還元のへマタイ トにより生じたと考えられる。

\section{$3 \cdot 4$ フェロコークスの強度支配因子の検討}

前節まで, フェロコークスの微視構造を検討し, 気孔壁 厚さ打よび“欠陥”を抽出し，HPCの配合がこれらに及ぼ す影響について検討した。本節では，抽出した“久陥”が強 度に及ぼす影響について検討し，フェロコークスの強度の 支配因子を検討する。Fig.10に試料A-D の三次元応力解析 から得られた最大主応力の平均值を示す。このとき, 分解 能が $32 \mu \mathrm{m} / \mathrm{pixel}$ であるため, $32 \mu \mathrm{m}$ 以下の気孔および基質 を評価することはできない。1つの試料のCT像から異なる 3つの三次元領域を解析した。その結果，HPCを配合する

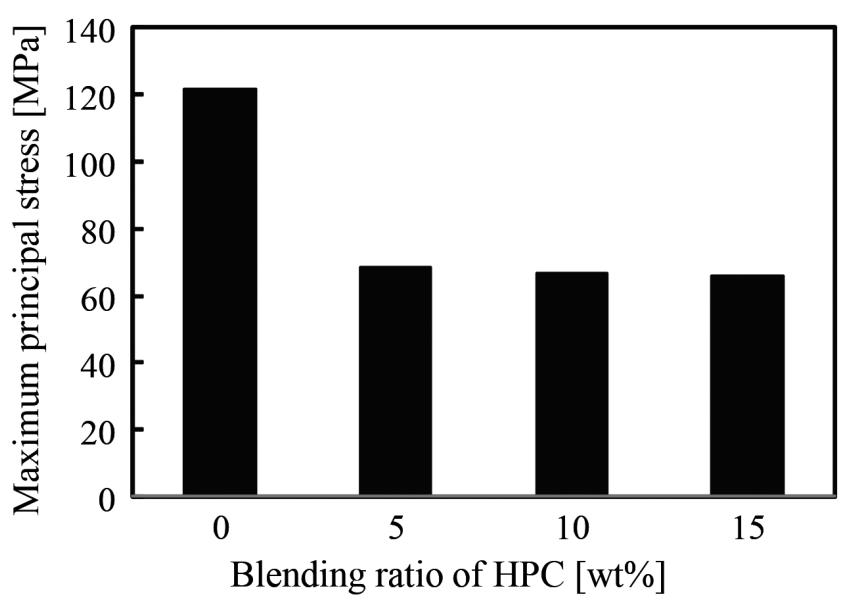

Fig. 10. Average maximum principal stress in the ferro-coke model for each blending ratio of HPC. 
ことにより最大主応力が低下し, 試料 B-Dに打いて最大主 応力の平均值に大きな差は現れなかった。そのため, HPC を配合することで石炭粒子の接着性が向上したことは明ら かであるものの, HPCの配合量を増加させても最大主応力 の平均值に大きな差は現れなかった。これはHPCの配合量 を増加させることで変化する $32 \mu \mathrm{m}$ 以下の基質打よび“久 陥”が応力解析に反映されなかったためであると考えられ る。次節では，最大主応力の平均值ではなく，最大主応力 自体について議論する。

\section{$3 \cdot 5$ フェロコークスの微視構造と応力集中部位の関係}

これまでの結果によりフェロコークスの強度支配因子が 石炭粒子の接着性向上にともない気孔壁が厚くなることが わかった。しかしながら，これらの結果は平均化した最大 主応力に着目しており, 微視構造の変化と微視構造に生じ ている応力の関係を理解するためには, 気孔壁厚さと微視 構造に生じた応力の関係を検討する必要がある。Fig.11に 試料 $\mathrm{D}$ の三次元応力解析から求めた応力分布の一例を示 し，Fig.12に試料A-Dに生じた最大主応力の割合を示す。 Hiraki ${ }^{13)}$ はコークス強度の向上に伴い三次元の気孔壁は 厚くなり，微視構造に生じる $5 \mathrm{MPa}$ 以上の最大主応力が生 じている基質が減少することを報告している。そこで, 横

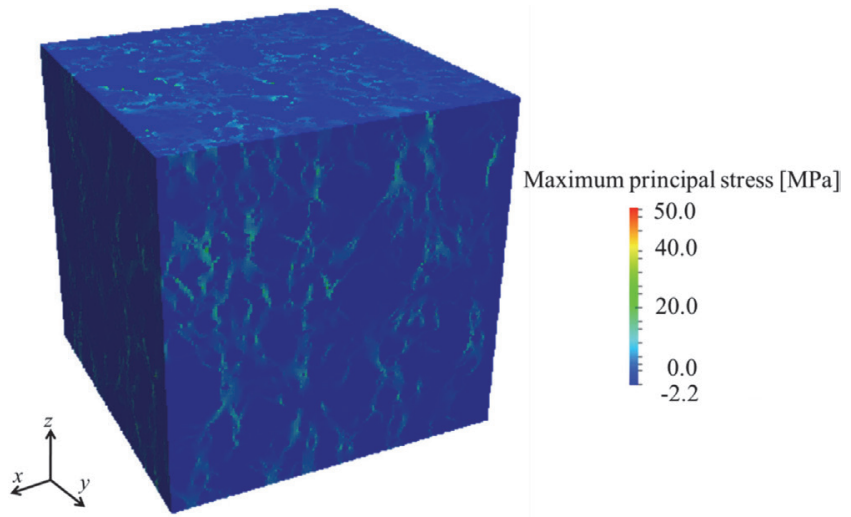

Fig. 11. Average maximum principal stress distribution in sample D. (Online version in color.)

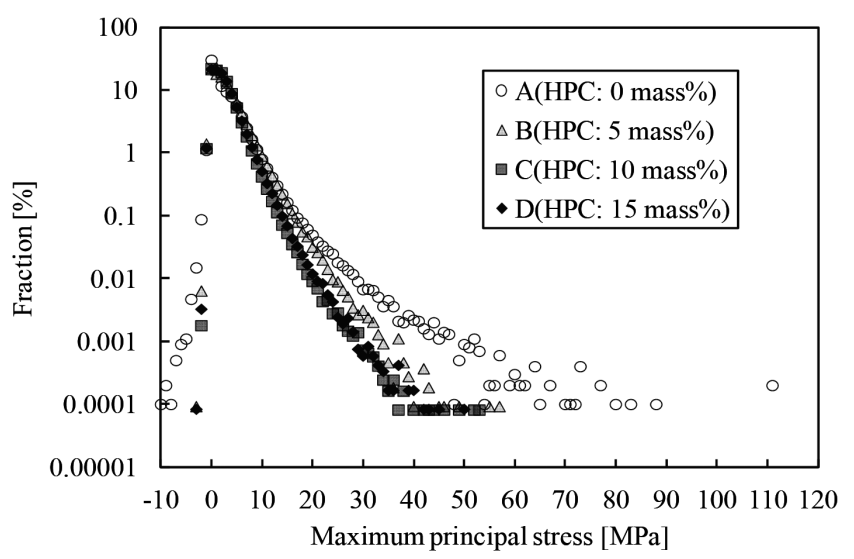

Fig. 12. Existence ratios with respect to maximum principal stress for samples A-D.
軸の $5 \mathrm{MPa}$ 以上の最大主応力が生じている基質に着目する と, HPCを配合しない試料A と比較して，HPCを配合した 試料B-Dでは $5 \mathrm{MPa}$ 以上の最大主応力が生じている基質の 割合は低下した。さらに，最大主応力はHPCの配合量の増 加に伴い減少するのに対し，Fig.10に示すとおり，この傾 向は最大主応力の平均值には表れない。これはHPCを配合 することで石炭粒子の接着性が向上し，フェロコークスの 微視構造に生じる応力が緩和されたためである考えられ る。したがって，石炭粒子の接着性が向上することでフェ ロコークスの微視構造に生じる最大主応力の分布は, 気孔 壁が厚くなるにともない変化すると考えられる。また, 最 大応力が生じる部位は破壊の起点となりうるため, この事 実は最大主応力の減少に伴いコークスの強度が増加するこ とを示唆している。

フェロコークスの微視構造に生じた応力分布を詳細に検 討するため，応力集中部位打よび気孔壁厚さを比較する。 Fig.13にFig.12に示した最大主応力の分布のうち number 1 で示される気孔壁に生じた最大主応力分布を示す。ここ で，フェロコークスの強度支配因子は石炭粒子が接着する ことで形成される微視構造の気孔壁厚さである。Fig.10に おいて, HPCの配合により石炭粒子の接着が向上するた め, コークス基質は連結し，コークスの微視組織に生じる 応力が緩和されることがわかった。さらに，気孔壁が薄い 基質のうち $5 \mathrm{MPa}$ 以上の応力が生じている基質がフェロ コークスの破壊に影響を及ぼすと考えられる。Fig.13に示 すと打り, number 1 に注目するとHPCを配合していない試 料A と比較して, HPCを配合した試料B-D は, $5 \mathrm{MPa}$ 以上 の応力が生じる基質の割合は低下した。これはHPC配合に より石炭粒子の接着性が向上し, 微視構造に生じる応力が 緩和され, 応力が集中する部位が減少することを示してい る。一方, Table 7に示し, 節 $3 \cdot 3$ で議論したとおり, HPC の配合によらず試料内に生成する “欠陥”による違いは確 認されない。したがって,コークスの強度は鉄粒子により

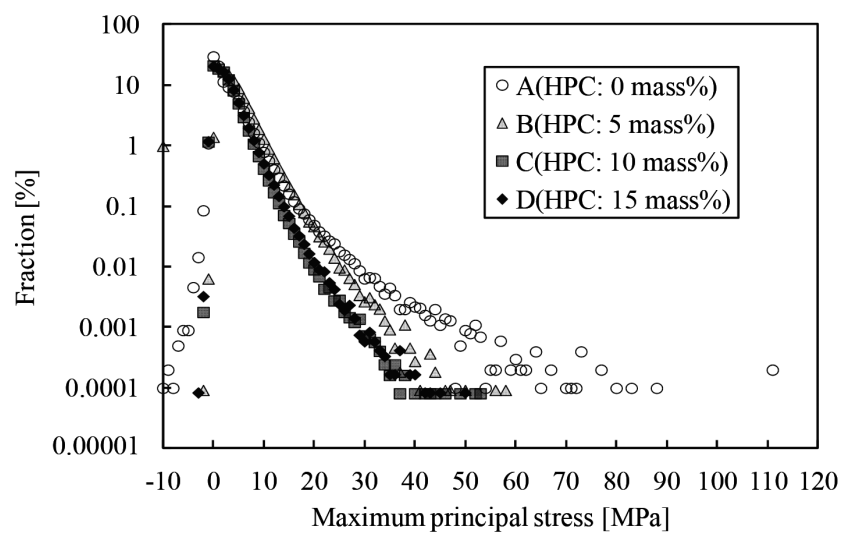

Fig. 13. Existence ratios with respect to maximum principal stress for samples A-D categorized by wall thickness number 1 . 
生じる “欠陥”よりも気孔壁厚さに依存すると考えられる。 以上より，HPCを配合することによって石炭粒子の接着が 向上することで，フェロコークスの微視組織に生じる応力 が分散し, 気孔壁が薄い部位への応力集中が緩和されるこ とで基質の破壊を抑制すると考えられる。

\section{4. 結言}

本研究では, フェロコークスの微視構造における気孔壁 厚さを評価した。また，フェロコークスのコークス基質お よび鉄粒子を抽出し，鉄粒子周辺における気孔を定量評価 することで, 石炭の再固化温度以降に打ける, 石炭と HPC の配合効果に及ぼす酸化鉄の影響について検討した。さら に, デジタルイメージに基づく有限要素法により, 応力解 析を行い, 配合比の異なるフェロコークスの微視構造にお ける応力分布とフェロコークスの微視構造の関係について 検討した。本研究は以下のようにまとめられる。

（1）HPCを配合することで気孔壁が厚い部位が増加する。 これはHPCを配合することで, 酸化鉄による石炭粒子 の膨張性の低下を抑制させることで石炭粒子の接着性 が良好となり, 石炭粒子の接着性が向上したためと考 えられる。

（2）鉄粒子周辺に生じる酸化鉄の還元反応により生じる “欠陥”はHPCの配合にかかわらず顕著な差が現れな かった。これは軟化溶融温度においてHPCを配合する ことでへマタイトがマグネタイトに還元されたためで あると考えられる。

（3）コークスの強度は酸化鉄の還元反応によりコークス基 質の減少に伴い生じた“欠陥”よりも気孔壁厚さの方 が強度に影響を及ぼす。

したがって，フェロコークスの強度を向上させるために， 軟化溶融温度における石炭粒子の接着性を向上させること が求められる。

\section{謝辞}

本研究の成果の一部は, 経済産業省事業「資源対応力強 化のための革新的製銑プロセス技術開発」に打いて（株） 神戸製鋼所からの業務委託により実施する「新規バイン ダーの強度開発機構の解明」の成果であることをここに記 し，謝意を表します。
Symbols

$E$ : elastic modulus $[\mathrm{Pa}]$

$F:$ body force $[\mathrm{Pa}]$

$u:$ displacement $[-]$

Greeks

$\varepsilon:$ strain $[-]$

$\sigma:$ stress $[\mathrm{Pa}]$

\section{文献}

1 ) I.Shimoyama: Tetsu-to-Hagané, 96(2010), 209 (in Japanese).

2 ) M.Shimizu and M.Naito: Tetsu-to-Hagané, 92(2006), 694 (in Japanese).

3 ) M.Naito, A.Okamoto, K.Yamaguchi, T.Yamaguchi and Y.Inoue: Tetsu-to-Hagané, 87(2001), 357 (in Japanese).

4 ) K.Higuchi, S.Nomura, K.Kunitomo, H.Yokoyama and M.Naito: Tetsu-to-Hagané, 98(2012), 517 (in Japanese).

5 ) M.Naito, S.Nomura and K.Kato: Tetsu-to-Hagané, 96(2010), 201 (in Japanese).

6 ) T.Yamamoto, T.Sato, H.Fujimoto, T.Anyashiki, K.Fukada, M.Sato, K.Takeda and T.Ariyama: Tetsu-to-Hagané, 97(2011), 501 (in Japanese).

7 ) S.Nomura, H.Terashima, E.Sato and M.Naito: Tetsu-to-Hagané, 92(2006), 849 (in Japanese).

8 ) Y.Yamazaki, H.Hayashizaki, K.Ueoka, K.Hiraki, Y.Matsushita, H.Aoki and T.Miura: Tetsu-to-Hagané, 96(2010), 536 (in Japanese).

9 ) T.Yamamoto, T.Sato, H.Fujimoto, T.Anyashiki, M.Sato and K.Takeda: Tetsu-to-Hagané, 96(2010), 683 (in Japanese).

10) N.Okuyama, T.Shigehisa, Y.Nishibata, K.Matsudaira and M.Nishimura: Tetsu-to-Hagané, 92(2006), 213 (in Japanese).

11) A.Uchida, T.Kanai, Y.Yamazaki, K.Hiraki, Y.Saito, H.Aoki, N.Komatsu, N.Okuyama and M.Hamaguchi: ISIJ Int., 53(2013), 403.

12) A.Uchida, Y.Yamazaki, K.Hiraki, T.Kanai, Y.Saito, H.Aoki, T.Inoue, N.Kikuchi, N.Okuyama and M.Hamaguchi: ISIJ Int., 53(2013), 1165.

13) K.Hiraki, Y.Yamazaki, T.Kanai, A.Uchida, Y.Saito, Y.Matsushita, H.Aoki, T.Miura, S.Nomura and H.Hayashizaki: ISIJ Int., 52(2012), 1966.

14) W.B.Lindquist, S.-M.Lee, D.A.Coker, K.W.Jones and P.Spanne: $J$. Geophys. Res., 101(1996), 8297.

15) Y.Yamamoto, Y.Kashiwaya, M.Nishimura and M.Kubota: Tetsu-toHagané, 95(2009), 103 (in Japanese).

16) G.Nagai, T.Yamada and A.Wada: J. Struct. Constr. Eng., 63(1998), No.509, 77 (in Japanese).

17) H.Hirashita, N.Takano, M.Sugisaki, S.Matsunaga and Y.Ide: Proc. 20th Computational Mechanics Division Conf., JSME, Tokyo, (2007), 385 (in Japanese).

18) K.Terada, T.Miura and N.Kikuchi: Compt. Mech., 20(1997), 331.

19) H.Hayashizaki, K.Ueoka, M.Kajiyama, Y.Yamazaki, K.Hiraki, Y.Matsushita, H.Aoki, T.Miura, K.Fukuda and K.Matsudaira: Tetsuto-Hagané, 95(2009), 593 (in Japanese).

20) K.Ueoka, T.Ogata, Y.Matsushita, Y.Morozumi, H.Aoki, T.Miura, K.Uebo and K.Fukuda: ISIJ Int., 47(2007), 1723.

21) Y.Yamazaki, H.Hayashizaki, K.Ueoka, K.Hiraki, Y.Matsushita, H.Aoki and T.Miura: Tetsu-to-Hagané, 96(2010), 536 (in Japanese).

22) T.Ogata, K.Ueoka, H.Hayashizaki, Y.Matsushita, H.Aoki, T.Miura, K.Fukuda and K.Matsudaira: Tetsu-to-Hagané, 93(2007), 736 (in Japanese). 